ELORE (ISSN 1456-3010), vol. 19 - 2/2012.

Julkaisija: Suomen Kansantietouden Tutkijain Seura ry.

[http://www.elore.fi/arkisto/2_12/hammarstrom.pdf]

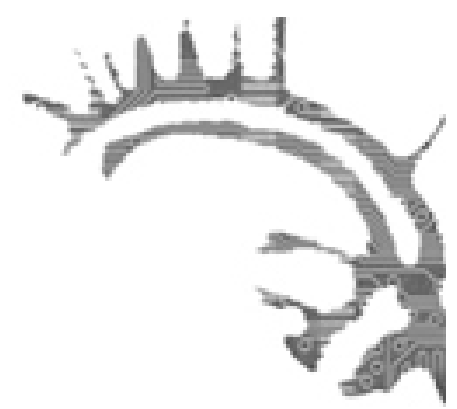

\title{
KIRJA-ARVIO
}

\section{MONIKULTTUURISET TYÖN JA OPISKELUN AREENAT}

PITKÄNEN, PIRKKO (toim.) 2011: Kulttuurien kohtaamisia arjessa. Tampere: Vastapaino. 240 sivua.

\section{Kukka Hammarström}

Ihmisten ylirajainen liikkuvuus ja kasvava kansainvälistyminen haastavat pohtimaan toimivan vuorovaikutuksen edellytyksiä erilaisilla arjen toiminta-alueilla. Kirjassa Kulttuurien kohtaamisia arjessa tarkastellaan kokemuksia monikulttuurisesta arjesta erilaisissa työ- ja opiskeluympäristöissä ja pohditaan samalla keinoja toimivan vuorovaikutuksen kehittämiseksi. Kirja perustuu Tampereen yliopiston tutkimushankkeeseen Sulkeutuuko Suomi? Kulttuurien välinen vuorovaikutus kohtaamisen areenoilla, joka toteutettiin vuosina 2008-2010. Tutkimukseen osallistuivat Tampereen yliopiston kasvatustieteiden laitos, Itä-Suomen yliopiston suomen kielen ja kulttuuritieteiden oppiaineryhmä ja Väestöliiton väestöntutkimuslaitos. Alueellisina vertailukohteina toimivat Helsingin, Tampereen ja Joensuun kaupungit.

Sujuva monikulttuurinen arki edellyttää myös yhtymäkohtien etsimistä, ei vain erilaisuuden tunnistamista. Kyse on molemminpuolisista oppimisprosesseista, ei pelkästään muualta tulleiden sopeuttamisesta. Olennaista on huomioida, että ihmisillä on monia muitakin identiteettejä kuin etninen ja kansallinen kulttuuri-identiteetti, ja että nekin ovat jatkuvassa muutoksessa. Esimerkiksi työkulttuuri saattaa olla ihmisiä yhdistävä tekijä, mutta työn ulkopuolella ei koeta yhteisyyttä siitä huolimatta, että edustetaan samaa 
kansallista kulttuuria. Nykyään tulisikin puhua ennemmin muuttuvasta ja dynaamisesta sosiaalisesta jäsenyydestä kuin yksipuolisesti kansallisuuteen ja etnisyyteen perustuvasta kulttuurikäsityksestä. Ihmisten kasvava ylirajainen liikkuvuus ja elämäntapa vaikuttavat siis väistämättä myös perinteiseen kuvaan kansallisvaltioon kuulumisesta ja identiteetin rakentumisesta.

\section{KULTTUURISTA VUOROVAIKUTUSTA ERILAISISSA TOIMINTAYMPÄRISTÖISSÄ}

Teoksessa on lyhyen esipuheen ja johdanto- sekä loppuluvun lisäksi seitsemän artikkelia. Kirjoittajia on kaikkiaan kuusi ja kolmessa artikkelissa on useampia kirjoittajia. Esipuheen ovat kirjoittaneet Peer Haataja (asiantuntija, EK) ja Auli Korhonen (erikoissuunnittelija, SAK) sekä johdantoluvun tutkimushankkeen johtaja professori Pirkko Pitkänen. Ensimmäisessä artikkelissa Mika Raunio, Minna Säävälä, Sari Hammar-Suutari ja Pirkko Pitkänen käyvät läpi erilaisia tutkimuksen kannalta olennaisia kulttuuria koskevia käsitteitä, kuten kulttuurien välinen vuorovaikutus, monikulttuurisuus, ylirajaisuus ja kulttuurinen kompetenssi. Tutkimuksen eri alueita yhdistävän areena-käsitteen tarkoitus on kuvata niitä toimintaympäristöjä, joissa kulttuurien kohtaaminen tapahtuu ja joissa kulttuuria myös tuotetaan. Niillä on omat suhteellisen vakiintuneet toimintakulttuurinsa, joilla pyritään toteuttamaan toiminnan tarkoitusta ja tavoitteita. Kyseisessä tutkimusprojektissa näitä areenoja edustavat terveydenhuollon, metallin ja korkean teknologian työyhteisöt sekä työvoimakoulutus ja korkeakouluopetus.

Toisessa artikkelissa Mika Raunio, Sari Hammar-Suutari ja Minna Säävälä tarkastelevat kaupunkiseutuja monikulttuurisen maahanmuuton ympäristöinä. Esimerkkeinä toimivat aiemmin mainitut Helsinki, Tampere ja Joensuu. Maahanmuuton toteutumiseen vaikuttavat sekä valtion yleiset linjaukset että kuntien omat toiminnot ja palvelut. Kaupunkiseutujen keskeisiä, vuorovaikutuksen reunaehtoja tuottavia toimintoja ovat muun muassa elinkeinorakenne, koulutuksen kansainvälisyys, maahanmuutto, monikulttuurisuus sekä paikallinen kehittäminen ja strategiat.

Seuraavat viisi artikkelia valottavat erilaisten toimintaympäristöjen kautta erilaisia kulttuurien kohtaamisen areenoja Suomessa. Pirkko Pitkänen kuvaa monikulttuurisen työyhteisön haasteita terveydenhuollon alueella, jossa kehitettävää löytyisi esimerkiksi työnohjauksessa sekä yleisemmin kulttuurienvälisissä vuorovaikutustaidoissa myös suomalaisten työntekijöiden osalta. Mika Raunion ja Minna Säävälän tekstissä tarkastellaan rinnakkain metallialan ja korkean teknologian työyhteisöjä. Kiinnostavaa on, että esimerkiksi asiapohjainen vuorovaikutus ja ohjeistus näyttävät toimivan paremmin hierarkkisessa, suorittavaa työtä tekevässä organisaatiossa kuin vastaavasti lähtökohdiltaan jo kansainvälisemmässä asiantuntijaorganisaatiossa. Sari Hammar-Suutarin monikulttuurista kulttuurityön kenttää käsittelevästä artikkelista käy ilmi, että vaikka Suomen kulttuuripolitiikassa on pyritty edistämään kotoutumista, kulttuurin saavutettavuutta ja monikulttuurista yhteiseloa, ovat etniseltä ja kulttuuriselta taustaltaan erilaiset kulttuurityön tekijät jääneet vähemmälle huomiolle. 
Minna Säävälä ja Elisa Keski-Hirvelä lähestyvät kirjoituksessaan kulttuurisesti monimuotoistuvan työvoimakoulutuksen haasteita. Osallisuuden edistäminen on eräs kehittämistä vaativa alue, joka edellyttäisi esimerkiksi enemmän monikulttuurisia koulutusryhmiä, joissa olisi sekä kantasuomalaisia että maahanmuuttajia. Niina Kovalainen tarkastelee korkeakoulutuksen areenaa kulttuurin välisen vuorovaikutuksen näkökulmasta. Artikkelista käy ilmi, että suomalaiset opiskelijat painottavat englannin kielen merkitystä selkeästi enemmän muihin vuorovaikutustaitoihin verrattuna. Myös muualta tulleiden opiskelijoiden kohdalla tulisi huomioida, että suomen kielen osaaminen on tärkeä opiskelun jälkeisen vaiheen, toisin sanoen yhteiskuntaan sopeutumisen sekä työllistyminen kannalta. Pirkko Pitkänen ja Mika Raunio kokoavat vielä viimeisessä artikkelissa yhteenvedon kirjassa käsitellyistä kysymyksistä, näkökulmista ja niistä tehdyistä johtopäätöksistä.

\section{MONINAISUUTTA JA YHTENÄISYYTTÄ OPPIMASSA}

Kirjassa on nostettu esiin erilaisia esimerkkejä niistä tekijöistä, joilla on merkitystä tai vaikutusta arjen sujumiseen erilaisissa työ- ja opiskeluympäristöissä. Ennakkoluuloilla ja kielteisillä asenteilla on yleensä vaikutusta vuorovaikutuksen sujumiseen. Huomionarvoista on, että sellaiset maahanmuuttajat ja kantaväestön edustajat, joilla on enemmän monikulttuurisia ystävyyssuhteita, suhtautuivat myönteisemmin kulttuurien väliseen vuorovaikutukseen ja eri taustoista tuleviin ihmisiin. Muualta tulleiden kokemuksissa suomalaisia ei nähdä kovinkaan hyvinä antamaan ja vastaanottamaan rakentavaa kritiikkiä. Myös hyvin järjestetyllä ohjauksella on merkitystä työn ja vuorovaikutuksen sujuvuuden kannalta. Työyhteisöissä tulisikin panostaa enemmän toimivaan ohjaus- ja palautejärjestelmään. Edellä mainittujen käytäntöjen lisäksi esiin nousivat myös sosiaalisten suhteiden ylläpitäminen ja yleinen kohteliaisuus, joissa suomalaisilla katsottiin olevan parantamisen varaa, ja joilla on vaikutusta kokemuksiin työ- ja opiskeluyhteisöjen sisäisestä toimintakulttuurista.

Kuten tutkimuksesta käy ilmi, alueelliset vaihtelut leimaavat maahanmuuttopolitiikkaa. Pääkaupunkiseutu on ollut tavoiteohjelmissaan aktiivisin, mutta kehitettäväälöytyy kaikkien kaupunkien osalta. Maahanmuuton moninaisuus ei esimerkiksi ole näkyvillä, vaan maahanmuuttajat on kategorisoitu kahteen kapeaan lokeroon: yhtäältä apua tarvitseviin ja sosiaalityön piiriin kuuluviin sekä toisaalta työn vuoksi maahan tuleviin, kansainvälisiin asiantuntijoihin. Linjauksissa painotetaan myös suvaitsevaisuutta, eikä niinkään molemminpuolista oppimista ja integraatiota.

Paikallisen kielen osaaminen näyttäytyy olennaisena osana toimivaa arkea, oli sitten kyse väliaikaisesta tai pysyvästä maassa oleskelusta. Käytetty yhteinen kieli, Suomessa usein englanti, voi toimia hyvässä mielessä neutraalina kommunikointialustana tai se voi olla olennainen osa vaikkapa kansainvälisen yrityksen ja työyhteisön arkea. Se ei kuitenkaan yksin riitä edistämään arjen sujuvuutta työn ja opiskelun ulkopuolisessa elämässä ja suomalaisessa yhteiskunnassa. Kielitaidon merkitys työ- ja opiskelupaikkojen sisäisessä toiminnassa vaihtelee riippuen millaisesta toiminnasta on kyse. Esimerkiksi 
terveydenhuollon piirissä suomen kielen taito on olennainen osa potilasturvallisuutta ja kommunikaatiota, toisaalta kulttuurityön alueella korostetaan enemmän taiteen omaa kieltä yhdistävänä tekijänä.

Erilaisten kulttuurien kohtaamisen areenoiden erot ja tilannekohtaisuus tulisikin huomioida kehitystyössä. Pirkko Pitkänen ja Mika Raunio toteavat viimeisessä luvussa seuraavasti: "Hyvin toimivien käytäntöjen hyödyntäminen ja toisten kokemuksista oppiminen ovat tärkeitä mietittäessä keinoja ulkomailta Suomeen muuttaneiden integroimiseen Suomen työ- ja yhteiskuntaelämään.” (s. 235.)

Kulttuurien kobtaamisia arjessa tekee kiinnostavan ja ajan tasalla olevan avauksen kulttuuria ja kulttuurien kohtaamista koskevaan tutkimukseen. Sen vahvuutena on monipuolinen ja konkreettinen lähestymistapa, joka tuo käsitellyn aiheen lähelle lukijaa. Erityismaininnan saa myös kolmas luku, joka valottaa erilaisia kulttuuria koskevia teoreettisia kysymyksiä ennen varsinaisia tapauskohtaisia käsittelylukuja. Kyse ei kuitenkaan ole vain teoreettisen lähestymistavan soveltamisesta vaan tarpeesta kehittää uusia ja toimivia käytäntöjä vuorovaikutuksen ja molemminpuolisen integraation edistämiseksi. Suosittelen kirjaa kaikille kulttuurin tutkimuksesta kiinnostuneille sekä niille, jotka kohtaavat ja pohtivat eri tavoin työssään monikulttuurisuuteen liittyviä kysymyksiä.

Filosofian maisteri Kukka Hammarström on folkloristiikan jatko-opiskelija Helsingin yliopistossa. 